\title{
Implementing New Public Management in Educational Policy
}

Citation for published version (APA):

van der Sluis, M. E., Reezigt, G. J., \& Borghans, L. (2017). Implementing New Public Management in Educational Policy. Educational Policy, 31(3), 303-329. https://doi.org/10.1177/0895904815598393

Document status and date:

Published: 01/05/2017

DOI:

10.1177/0895904815598393

Document Version:

Publisher's PDF, also known as Version of record

Document license:

Taverne

Please check the document version of this publication:

- A submitted manuscript is the version of the article upon submission and before peer-review. There can be important differences between the submitted version and the official published version of record.

People interested in the research are advised to contact the author for the final version of the publication, or visit the DOI to the publisher's website.

- The final author version and the galley proof are versions of the publication after peer review.

- The final published version features the final layout of the paper including the volume, issue and page numbers.

Link to publication

\footnotetext{
General rights rights.

- You may freely distribute the URL identifying the publication in the public portal. please follow below link for the End User Agreement:

www.umlib.nl/taverne-license

Take down policy

If you believe that this document breaches copyright please contact us at:

repository@maastrichtuniversity.nl

providing details and we will investigate your claim.
}

Copyright and moral rights for the publications made accessible in the public portal are retained by the authors and/or other copyright owners and it is a condition of accessing publications that users recognise and abide by the legal requirements associated with these

- Users may download and print one copy of any publication from the public portal for the purpose of private study or research.

- You may not further distribute the material or use it for any profit-making activity or commercial gain

If the publication is distributed under the terms of Article $25 \mathrm{fa}$ of the Dutch Copyright Act, indicated by the "Taverne" license above, 


\title{
Implementing New Public Management in Educational Policy
}

\section{Margriet E. van der Sluis ${ }^{1,2}$, Gerry J. Reezigt', and Lex Borghans ${ }^{2}$}

\begin{abstract}
This article describes how the Dutch Department of Education incorporates New Public Management (NPM) principles in educational policy, and whether conflicts of interest between the Department and schools cause deviations from NPM. We reviewed policy documents and performed secondary analyses on school data. Educational policy focuses on output indicators and accountability aspects. However, when departmental interests do not align with school interests, the Department develops new policies that partly contradict NPM principles. We argue that a more consistent focus on output and well-developed school autonomy may help to enhance the quality of education
\end{abstract}

\section{Keywords}

policy implementation, school governance, supervision

\section{Introduction}

From the 1980s onward, countries worldwide introduced reforms that were marked by the term New Public Management (NPM hereafter). The reforms

\footnotetext{
'Inspectorate of Education, The Netherlands

2Maastricht University, The Netherlands

Corresponding Author:

Gerry J. Reezigt, Inspectorate of Education, P.O. Box 2730, Utrecht, 3500 GS,

The Netherlands.

Email: g.reezigt@owinsp.nl
} 
took place in various societal domains, one of which is the educational system. NPM influenced educational policy in, for example, the United States, Australia, Korea, Lithuania, and several countries in Western Europe such as the Netherlands. Because of political and economic differences between countries, the reforms took place in different decades and contexts (Braun \& Merrien, 1999; Byun, 2008; Fusarelli \& Johnson, 2004; Leisyte \& Kizniene, 2006). The main aim of NPM was to make educational policy more effective and more efficient. Often, budget reductions were also at stake.

In the Netherlands, one of the key features of NPM in education is the changing relationship between the Department of Education, Culture, and Science (Department hereafter) and schools. The Department changes its policy from a traditional input-oriented model of detailed and direct departmental interference with educational processes of schools to a much less prescriptive and output-oriented model. To control educational quality, the Department monitors quality by means of output indicators, and departmental powers are deregulated to schools by law. Schools in their turn gain more autonomy and are free to decide independent of the Department how they want to design educational practice, as long as they meet the output criteria set by the Department. By these changes, the main aim of NPM, a more efficient and effective regulation of education, is supposed to be achieved.

A complicating factor in NPM policy is that national goals that the Department wants to achieve not necessarily equal goals of individual schools. The Department and schools are different actors in the educational arena, each with their own set of values and interests, which may sometimes conflict (Cedefop, 2010; Clarke \& Winch, 2007; Leney \& Green, 2005; Taylor, 2009; van der Sluis, Reezigt, \& Borghans, 2014). For example, a school may want to expel students who do not perform well or cause trouble although they have not graduated yet, while the Department strongly stresses that each and every student must get their degree before leaving school. As a consequence, the Department cannot easily assume that schools will comply and might feel the need to intervene. Ideally, the Department knows when interventions are needed (on issues where diverging opinions may hinder the achievement of national aims, and in NPM these are primarily output issues) and when not (when schools hold the same opinions as the Department does and act accordingly), so that the autonomy granted to schools will stay intact as much as possible.

We are interested in studying to what extent the Dutch Department actually incorporated NPM in its vocational education policy over the past decade. By this, we mean that educational policy should concentrate on the output of schools and accountability issues, no longer on teaching and learning processes. Furthermore, we want to find out whether the government 
diverges from its NPM principles when there is a conflict of interest with schools. To answer these questions, we first analyzed three types of policy documents. We conclude that elements of educational policy certainly match NPM assumptions. There is a strong focus on output indicators, such as the reduction of the number of early school leavers, and self-governance of schools is stimulated. At the same time, interference with educational processes did not disappear, and the Department sometimes seems to act inconsistently by introducing policies that affect these processes. Second, we performed secondary analyses on data of a case study on stakeholder values in Dutch vocational education. We found that our expectations were only partially met. The Department does tend to invest more strongly in output issues when its concerns are not fully met by the schools' concerns. Here too, however, there are exceptions. The policy attention for the quality of examinations, for example, is extensive, even though schools regard this topic as highly important as well.

\section{The Concept of NPM}

The concept of NPM refers to a management culture that influenced the public sector in many countries, including the educational sector. Compared with the private sector, the public sector had acquired a reputation of being less effective and efficient, and therefore it was supposedly too expensive. To change this, policy makers introduced ideas and techniques of the private sector into the public sector, such as outcome-based accountability and market driven management. NPM reforms generally pursued aims such as the improvement of the effectiveness and efficiency of the public sector, the enhancement of responsiveness of public agencies to their clients and customers, the reduction of public expenditures, and the improvement of managerial accountability. NPM reforms were implemented to different degrees and with different emphases. NPM still is a relevant framework in discussions on educational policy. It is very much alive in many countries, and NPM reforms so far have not been replaced by new policy reforms, although they may be revised or followed up by post-NPM reforms (Christensen \& Laegreid, 2007).

\section{NPM in Education}

The introduction of NPM had varying consequences for educational systems throughout the world, but there are common features as well. We focus on two widespread elements of NPM in education: the focus on the output of schools and governmental deregulation. 
NPM is characterized by an output-oriented governance model. This means that the national government, that is, the Department of Education, sets objectives in line with their vision on education and accordingly constructs performance measures (national tests, standards, targets, benchmarks) to monitor the extent to which schools achieve these objectives. Monitor output data are used as a basis for decision making on the future allocation and management of resources, and the development of policy programs. Monitor output data are also used to inform educational stakeholders and society at large (Lindgren, 2001). Output control by means of indicators enables the Department to loosen the reins in other areas, such as educational processes in schools.

This refers to governmental deregulation, another key characteristic of NPM. Many decisions once taken by the Department are now being taken by schools. The Department still funds schools, but schools are highly autonomous in their planning and budgeting, resource allocations, hiring and firing, as well as in evaluating and monitoring their quality. In his analysis of the impact of public management reform Pollitt (2000) refers to this as the "steer not row" principle; the reformed governments become more concerned with strategy and less with the process of carrying-out. Consequently, the freedom of schools to design educational processes becomes larger. It was expected that this principle would lead to more effective ways of governing, because schools are closer to the educational process than the national Department. Students are also supposed to benefit, because NPM emphasizes the centrality of "customers" (Tolofari, 2005). For schools, this means they should try to tailor education to the needs of their students.

The effects of NPM in education are often questioned. Pollitt (2000) looks at available evidence on the results of public management reforms through Organisation for Economic Co-Operation and Development (OECD) countries and concludes that, although there is evidence of improvements in particular instances, the general case for NPM as a solution to diverse problems of governance in many different countries is not firmly established. Especially, the achievement of a more effective (as distinct from more efficient) government is hard to demonstrate. There are a lot of conceptual and methodological problems about what the available data can be said to show (Baker et al., 2010) and to what effects should be attributed. Studies that do systematically look for the effects have mixed outcomes (see, for example, Andersen, 2008).

Concerning the supposed deregulation and autonomy studies sometimes reveal that policy programs take away the initiative of schools rather than to entrust them with new responsibilities (Byun, 2008; Honig \& Rainey, 2012; Leisyte \& Kizniene, 2006). Furthermore, it is argued that we cannot expect 
market-based management techniques embodied in NPM to be equally effective when applied to schools (Fusarelli \& Johnson, 2004). Output indicators, for example, are not always sufficient motivators for improving schools (Fusarelli \& Johnson, 2004; Lindgren, 2001). Educational outcomes are also diverse and complex, and difficult to define, measure, and interpret. Because of this, it is hard for schools to act like private sector firms. Some scientists specifically warn against the complicated combination of autonomy and departmental control. For educational departments, letting go of their traditional forms of control on one hand and developing output control on the other hand appears to be rather complex. NPM in practice sometimes shows both centralizing and deregulatory elements (Tolofari, 2005). Over the last two decades, it became increasingly clear that deregulation is often coupled with re-regulation and more scrutiny and control by national governments (Christensen \& Laegreid, 2007). Balancing control and autonomy is getting increasingly complex in (post)-NPM reforms. Tolofari (2005) argues that schools may become more powerful and more entrepreneurial to keep up their finances, while educational departments demand parsimony and output measurement that might result in bureaucratic control limiting autonomy. In sum, studies show that the theory and practice of NPM are often worlds apart.

\section{Research Questions}

In our study, we will elaborate on the concept and practice of NPM in the Netherlands. We want to know whether educational policy makers, that is, the Dutch Department of Education, Culture, and Science, behave in line with NPM assumptions. According to NPM, policy makers should mainly be output oriented and less prescriptive on educational processes. However, we hypothesize that it will be hard for policy makers to merely concentrate on output and to stop interfering with educational processes in the way they were used to. We therefore studied whether policy makers and schools hold different opinions on educational issues. We also studied whether educational policy keeps focusing on output issues when schools hold opinions that may hinder the achievement of policy makers' goals. Our research questions are as follows:

Research Question 1: To what extent is Dutch policy on vocational education consistent with the concept of NPM?

Research Question 2: Does the Department divert from the concept of NPM when there is a conflict of interest with the schools? 


\section{Contribution to the Literature}

This study contributes to the literature on the practice of implementing NPM in national educational policies, and the involvement of government officials and school representatives in this process. Leisyte and Kizniene (2006) investigate the implementation of NPM in Lithuania's higher education. In 2000 , a regulatory framework set the conditions for the higher education institutions' autonomy and prescribed limits to state regulation. The authors question whether this framework actually changed university management and academic work in Lithuania. Interviews with stakeholders help declare why academics, school managers, stakeholders, as well as state officials are still not clear about what NPM means in practice for Lithuanian universities nor how this new agenda would affect them. One of the difficulties is that the managerial self-governance, for example, involving stakeholders and managerial experience of the university top, seems not yet at the required level. Hangartner and Svaton (2013) study the reform of compulsory schooling in the Swiss education system. The reform started with some "hard core" NPM ideas such as increased school autonomy, educational markets, and performance pay for teachers. However, mainly governments and administrations showed interest in the reforms, while legislative bodies and citizens reacted rather reluctantly. Shaped by several pilot studies and an extensive political debate, the proposed reform gradually changed. Teachers objected to the idea of the introduction of external school evaluation because it would hinder school-based development. Furthermore, many Swiss cantons extended school autonomy only hesitantly because pilot studies did not show clear positive results. The actual reform was a downsized version of NPM and focused mainly on the introduction of headteachers (in addition to school boards) and the implementation of school quality management procedures. Byun (2008) studies the effects of NPM on Korean higher education. He argues that the general cynical attitudes held by most professors toward the NPM governance model is one of the main reasons that hindered the NPM governance principles from being deeply incorporated into the Korean universities. The main objection concerned the movement toward strong executive leadership and state intervention by means of various accountability measures. Another objection was the lack of a necessary coherence of government policies over the past two decades, in particular, a heavy emphasis on accountability without an accompanying increase in institutional autonomy.

The studies above show that in the process of implementing NPM, governments can meet strong resistance from school representatives. This resistance seems to be grounded in an uncertainty of schools about how NPM will 
affect them. Apparently, governments do not to succeed in providing clarity about the intentions of their policies and their expectations regarding the role of schools. The contribution of our article is that we focus on the government as an actor in the implementation process and investigate in detail the process of adopting NPM in education policy. Unclear or inconsistent policy can be an explanation for the dubious effectiveness of NPM in education systems.

\section{Dutch Vocational Education in the Context of NPM}

We study our research questions in the setting of Dutch vocational education, because in this educational sector, the tension between school autonomy and governmental interference is clearly present. On one hand, vocational schools are large educational institutes, comparable with institutes that offer higher education, that define to a large extent their own processes. On the other hand, vocational institutes offer compulsory education for students from age 16, which causes extra responsibility for the government. Furthermore, Dutch vocational education was one of the sectors where NPM policies were implemented first and where nowadays a lot of experience is gained with these policies. Before we explain our method, we will discuss the setting further.

In the Netherlands, senior secondary vocational education and training (VET) is organized in vocational schools. These schools offer courses at four levels of increasing difficulty. In 2010, more than 485,000 Dutch students aged 16 and older were enrolled in vocational education. Students can choose between a school-based learning route and a work-based route (combining work and school). Schools offer courses in four vocational domains: technology, commerce/administration, services/health, and agriculture. Vocational education policy is based on the law of vocational education (WEB). According to this law, vocational education should provide students not only with sufficient theoretical and practical tools for their future jobs but also with basic skills in literacy, numeracy, and civic functioning.

NPM was introduced in Dutch vocational education in 1985, when a large-scale process of departmental deregulation started and changed this sector completely. Other educational sectors followed later. In 1992, the Dutch Department of Education started providing lump sum funding to all vocational schools (Karsten \& Meijer, 1999). With lump sum funding, schools are free to spend their budget as they wish. By this, the Department aims to stimulate schools to be responsible for educational quality and operational management, while the Department itself manages the educational sector by setting and monitoring output standards (Karsten \& Meijer, 1999). In the lump sum system, the production of education is outsourced to independently operating boards at the school level. The school's main budget is 
allocated by means of standardized formulae and increases with the numbers of students. In addition, incentives were built into the lump sum system. For example, schools can acquire additional funding based on the number of students who graduate successfully. With the introduction of the lump sum funding system, schools became autonomous in deciding about topics like class size and didactic approaches. For example, it was no longer mandatory for all students to stay in the same class, studying the same subjects, for a full year (Karsten \& Meijer, 1999). This fits well in the Dutch education system where the autonomy of schools historically is firmly upheld. However, some output goals that are central for the Department transcend the interests of individual vocational schools. When schools are highly autonomous, it is not selfevident anymore that they will pursue these goals as strongly as the Department wants them to. These output goals are, for example, all students should obtain diplomas, all students have to master basic literacy and numeracy skills when they graduate, and all students acquire knowledge and skills in the area of citizenship. For a school, numeracy standards or citizenship development may not be very important, especially when stakeholders (parents, students, employers) attach little importance to them. This led us to hypothesize that the Department may feel the need to interfere when schools hold different opinions on policy topics.

\section{Method}

To answer our research questions, we combine content analysis of reports with a secondary analysis of data from a study on stakeholder values in Dutch vocational education.

\section{Content Analysis of Reports}

For our first research question, we applied this analysis to documents from three sources: reports of the Department of Education, the Inspectorate of Education, and the Dutch Education Council. We analyzed the content of reports published between 2000 and 2010, thereby covering a 10-year policy term. The implementation of NPM in Dutch vocational education started a few years before the year 2000, but unfortunately a systematic analysis of this earlier period was not possible. Policy programs were not set out explicitly, and departmental reports were not systematically structured to report about similar policy topics year after year. From 2000 onward, the reports showed more consistency. We studied a decade because that allowed us to see which policy programs were important for a longer period of time, indicated by the budget or attention they received. To select 
the content of the reports for this study, we used different methods. In case of the annual reports, we made a top five of policy programs on vocational education based on the number of pages every topic receives and the expenditures. The programs that got less than one page policy attention and that were given relatively little money were left out, because those are believed to have little impact in the education practice. In case of the reports of the Inspectorate of Education and the Education Council, we selected all the reports about vocational education and about aspects of NPM in specific.

Annual departmental financial reports 2000-2010 of the Department of Education, Culture, and Science. The departmental financial reports are published yearly and show how the budget is spent on policy programs in the preceding year. The reports also give insight in the content and progress of these programs. ${ }^{1}$ Our aim was to see to what extent educational policy is consistent with the concept of NPM. To answer this research question, we first selected policy topics that received a lot of attention throughout the years. We then measured the degree of attention given to a specific policy topic in the field of vocational education by counting the number of pages in the financial reports about this topic. The reports from the years 2007 to 2010 enabled us to add the money spent on each topic as an additional indicator of policy attention. In reports from earlier years, the differences in budget specification unfortunately were too substantial to do the same.

Reports of the Inspectorate of Education. The Dutch Inspectorate of Education is part of the Department of Education. We studied inspection frameworks and thematic reports. Inspection frameworks outline the aims and methods of school inspection for a period of 2 to 4 years. They comprise the indicators used by inspectors to make judgments about vocational schools. These frameworks were relevant because they informed us about the prevailing ideas about the relationship between the Department and schools. For example, when the Department focuses on output control according to the concept of NPM, it would be surprising to find the inspection framework focusing on educational processes in schools. We studied the main statements about the Department-schools relationships in the inspection frameworks of 2003, 2007 , and 2009. Thematic reports describe research results of studies by the Inspectorate. The subjects of these reports make clear what the main policy topics in vocational education are, according to the Inspectorate and the Department. For this study, we selected all the thematic reports about vocational education and checked how often specific subjects were examined between 2000 and 2010 . 
Reports of the Dutch Education Council. The Education Council is an independent advisory body that provides advice, both solicited and unsolicited, to the Department of Education. For this study, we were especially interested in reports requested by the Department, because we wanted to know to what extent these reports reflect the concept of NPM. First, we selected every report requested by the Department about vocational education. Second, we selected all reports about the (changing) relationship between the Department and schools.

\section{Secondary Analysis of Data on Stakeholder Values in Dutch VET}

For our second research question, we performed secondary analyses on data of a study that was conducted in vocational education in 2010 . This study measured the degree of agreement about educational topics between the Department and vocational schools by means of a questionnaire. The main goal of this study was to quantify stakeholder values of vocational education in the Netherlands (van der Sluis et al., 2014). Stakeholders were students, parents, employers, school representatives, and departmental representatives. The data do not provide a representative sample of the wider field of schools and policy makers in vocational education. However, several attempts were made to provide a suitable sample. Firstly, the data were collected in the business as well as in the technology and service/healthcare sector. Second, in each sector, one of the more mainstream courses (with a large student population) at Level 4 was selected. ${ }^{2}$ Third, the gender of the course population was taken into account. These conditions led to the selection of the following three VET courses:

- Social pedagogical studies (service/health care sector, mainly female),

- Administrative studies (commerce/administration sector, mixed), and

- Construction studies (technology sector, mainly male)

Each course was visited at three different colleges resulting in nine courses in total. The three colleges are spread across the Netherlands and are similar in their socioeconomic status (SES) compositions, with an average of $30 \%$ of nonnative students. Per course, around 35 students, depending on class size, and all teachers were approached. During the visit, all the present students, teachers, and school managers completed the questionnaire on the spot. The teachers who were not present were later approached by email. Of that group, the response rate was $40 \%$. Departmental representatives were approached separately. Our analyses concerned the data of school representatives and departmental representatives 
and measured the perceived importance of topics about processes and output in vocational education.

The questionnaire consisted of statements about vocational education. Respondents were asked to value each statement on a 10-point scale, in which 5 indicates $I$ find this very important, 0 stands for neutral, and -5 means I'd rather not have this. The statements were presented to the respondents in random order. For the present study, we selected the following nine statements that explicitly refer to educational output (such as employer satisfaction) and educational processes (such as frontal instruction) of vocational education.

1. Preventing students from leaving the school early is an important issue at the school.

2. Employers appreciate graduates of this course.

3. In this course, attention is paid to the mathematical skills of the students.

4. In this course, attention is paid to the Dutch language.

5. The tests of this course are of good quality.

6. The course makes use of frontal instruction.

7. The students are offered challenging assignments during the course.

8. Students of this course are mentored sufficiently during the workplace learning period.

9. The course has many hours per week.

The questions did not vary between the stakeholders and were presented in random order.

As this study focuses on the relationship between the Department and schools, we concentrated on the data of 54 departmental representatives (18 policy makers of the Department and 36 vocational education inspectors of the Inspectorate of Education) and 75 school representatives (66 teachers and 9 managers of five vocational schools). We calculated mean scores per topic for each of these two groups and used $t$ tests to find out whether differences in scores were statistically significant. As a next step, we confronted the agreement on topics with the level of policy attention these topics had in the documents we analyzed.

\section{Results}

\section{Consistency of Educational Policy and the Concept of NPM}

Our first research question states to what extent educational policy is consistent with the concept of NPM. To answer this question, we will describe the results 
Table I. Policy Attention Measured in Numbers of Pages (2000-2010) and Expenditures (2007-2010).

\begin{tabular}{lcc}
\hline Policy programs & $\begin{array}{c}\text { Total number of } \\
\text { pages in 2000-2010a }\end{array}$ & $\begin{array}{c}\text { Expenditures in } \\
2007-2010(\times 1.000)\end{array}$ \\
\hline Reduction of early school leaving & 20 & $€ 356,552$ \\
Innovation budgeting & 10 & $€ 382,505$ \\
Quality of examinations & 8 & $€ I I, 300$ \\
Reform of qualification structure & 5 & $€ 18,785$ \\
Literacy and numeracy standards & 1 & $€ 79,962$
\end{tabular}

aThe total number of pages about policy programs in vocational education in 2000 to 2010 was 88 (on average 8 pages per year).

of our analysis of three types of documents. In doing so, we will concentrate on two main characteristics of NPM: a focus on output and school autonomy.

\section{Annual Departmental Reports (2000-2010)}

The five topics receiving the highest levels of policy attention in 2000 to 2010 are reduction of early school leaving, innovation budgeting, quality of examinations, reform of qualification structure, and literacy and numeracy standards. They will be discussed below.

Reduction of early school leaving. This topic is strongly influenced by the goals set by European education ministers in Lisbon in 2000. In the first years after 2000 , the Department is primarily concerned with methods to adequately register early school leavers. Later reports show the number of early school leavers is gradually reducing. Over the years, this topic became a large policy program consisting of many projects. In 2010 , the policy program on early school leaving contains projects on the maintenance of regional registration centers, the formulation of target agreements (between schools, the minister, and the regional registration centers), digital systems for the registration of absenteeism, facilities for overloaded students, and social work in schools (to prevent early school leaving). In 2007 to 2010, a lot of money was spent on the reduction of early school leaving compared with other policy topics. The topic of early school leaving also dominates other topics with regard to the number of pages it comprises in annual reports (Table 1).

Innovation budgeting. In 2000, the Department provides funding for innovations in vocational schools. Plans of schools aiming at improving the transition of students from secondary to tertiary vocational education or improving 
connections with the labor market are funded on top of the lump sum. From 2000 to 2010, a major part of the budget is spent on these innovative projects. The annual reports do not give systematic information about effects of the projects.

Quality of examinations. In Dutch vocational education, students must show that they are qualified for the jobs they were trained for in their exams. The exam guarantees the formal qualification of students and reflects the level and content of job training. In 2000, the Department starts providing additional funding to improve the quality of exams, and up to 2010, the quality of the exams is an ongoing concern in many annual reports. In 2002, the responsibility for the quality of examination, which belonged to the Inspectorate of Education, was transferred to the Quality Examination Center. The results of this organizational change are disappointing, however, and in 2008, the Inspectorate is once again made responsible for the quality of examinations in vocational education. These events lead to a considerable amount of departmental attention through the years. The expenditures in 2007 to 2010 are not in line with that, but this is due to the fact that costs for exams are funded in the lump sum.

Reform of qualification structure. In 2002, the Department starts reforming the vocational qualification structure, that is, the full set of qualification dossiers of vocational educational levels. A qualification dossier specifies the knowledge, skills, and competencies for a particular diploma. It states what a student should know and be able to do to get a diploma. The main goal was to make qualifications more transparent, to guide the output of vocational courses, and to align educational contents more closely with the demands of the labor market. The Department combined the structural reform with a pedagogical reform: Vocational education had to become competence-based, and courses were supposed to become more challenging and attractive by stronger links to professional practice. Furthermore, teachers were to vary their teaching methods more, for example, by alternating frontal instruction and working in groups. During 2000 to 2010, the Department reports repeatedly on the changes on the way to competence-based vocational education.

Literacy and numeracy standards. Since 2008, the policy attention for literacy and numeracy standards is substantial. In 2006, the Dutch Education Council stated that cognitive skills in education were under pressure. The Council recommended that schools should improve the monitoring of students' levels of knowledge and repair knowledge gaps in Dutch language and mathematics (Onderwijsraad, 2006). Starting in 2008, the Department generates a budget for the enforcement of literacy and numeracy education in vocational schools. 
On August 1, 2010, the law on "Reference Levels for Dutch language and mathematics" comes into force. Vocational schools are then required to use reference levels for language and math in addition to vocational requirements. The Department obliges Level 4 students to take central examinations in language and math to get their diploma. Such examinations are new in vocational education.

Conclusion. In the departmental reports, we see aspects that align with the concept of NPM. Many policy topics reflect a focus on the output of education: the reduction of early school leaving, the quality of examinations, and literacy and numeracy standards. We also see that the Department provides school with unearmarked resources for innovation on top of their lump sum budgets. Schools can decide independently how they want to spend their innovation budgets to achieve their goals. This too fits into the NPM concept. Other policy actions, however, are in conflict with NPM: By forcing a pedagogical reform on vocational schools, the Department interferes with their autonomy and subverts their discretion in designing educational processes.

\section{Reports of the Inspectorate of Education in 2000 to 2010}

The Dutch Inspectorate of Education assesses the quality of vocational schools. Currently, vocational schools are visited every 3 years. An inspection takes place at course level and consists of interviews with students, teachers, the school board, and staff members. Inspectors also observe lessons and analyze school documents. When courses are below inspection norms, they are judged as "weak." Quality care is an important factor to decide for further investigation. During 2000 to 2010, the Inspectorate stimulated vocational schools to be responsible for the quality of education, examinations, and operational management. We studied inspection frameworks and thematic reports.

Inspection frameworks. The inspection framework of 2003 not only contains legal requirements schools must meet but also ascribes a large degree of autonomy to schools. The Inspectorate works according to the proportionality principle: The interference of the Inspectorate is dependent on the extent to which schools make their governance processes visible and reliable. The more they do this, the less extensive inspection will be. The Inspectorate proclaims self-evaluations of schools as the most important documents for inspection (Inspectie van het Onderwijs, 2003).

In the 2007 framework, the Inspectorate again strongly focuses on the quality of self-governance of vocational schools by stimulating the professionalism 
Table 2. Subjects of Thematic Reports by the Inspectorate of Education on Vocational Education 2000-2010.

\begin{tabular}{lc}
\hline & Number of reports \\
\hline The quality of examinations & 7 \\
Compliance with the 850-hr standard & 4 \\
Early school leaving & 3 \\
Reform of qualification structure/competence based & 2 \\
$\quad$ education & 2 \\
Complaint procedures of schools & $\mathrm{I}$ \\
Self-governance of schools & $\mathrm{I}$ \\
Literacy standards & $\mathrm{I}$ \\
The quality of workplace learning & $\mathrm{I}$ \\
Labor market perspective & \\
\hline
\end{tabular}

of school boards. Also, schools are legally obliged to install a board of supervisors to control the executive board (Inspectie van het Onderwijs, 2007a).

In 2009, the Inspectorate starts using methods of risk analysis. Through self-evaluations, accountability data, and indicators such as the graduation rates of students, the Inspectorate monitors all vocational schools. The Inspectorate only intervenes at institutions which show risks in their output and have underdeveloped quality assurance systems. When schools are sufficiently capable of monitoring and improving their educational quality, the Inspectorate keeps its distance (Inspectie van het Onderwijs, 2010a).

Thematic reports. The Inspectorate publishes thematic reports when a sample of vocational schools is investigated to answer specific research questions. These activities are separate from the regular inspection visits described above. Table 2 shows the subjects of the thematic reports and the number of reports per subject.

Table 2 shows four subjects that also came up in the annual departmental reports: the quality of examination, early school leaving, the reform of the qualification structure and the implementation of competence-based education, and literacy.

The remaining subjects are specific for the Inspectorate.

- Compliance of schools with the 850-hr standard: Vocational schools are legally required to offer $850 \mathrm{hr}$ per year to full-time students. At the request of the Department, the Inspectorate repeatedly investigated the compliance with this law (Inspectie van het Onderwijs, 2006a, 2007b, 
2007c, 2009a), because many schools did not live up to the $850-\mathrm{hr}$ standard.

- Complaint procedures: The code for good governance in vocational education of 2009 included many recommendations for complaint procedures (e.g., appoint a committee that treats complaints objectively and independently, give optimal information to students, and appoint a person in whom students can confide and to whom they can address complaints). The Inspectorate found that in 2009, a majority of schools did not have adequate procedures; a follow-up study took place in 2010 (Inspectie van het Onderwijs, 2009b, 2010b).

- Self-governance of schools: In 2010, the inspectorate presents a study in which a correlation is demonstrated between the quality assurance capacity of a vocational school and the quality of education; institutions with a higher education quality often know a functioning quality assurance and greater organizational effectiveness. At the same time, they find that only a small proportion of the schools meet the conditions for good self-governance. Only about $15 \%$ of institutions have a good quality assurance capacity as well as a large organizational effectiveness and high education quality (Inspectie van het Onderwijs, 2010c).

- Quality of workplace learning: The Inspectorate monitors the quality of workplace learning, an important part of Dutch vocational courses. The report discusses topics such as the availability and accreditation of workplace learning places, and the (changing) relationship between learning in school and learning in workplaces (Inspectie van het Onderwijs, 2006b).

- Labor market perspective: Since 2008, vocational schools are legally obliged to only offer courses with sufficient labor market perspective for students. In addition, they must inform students about employment opportunities. The Inspectorate exploratively studied in 2009 how schools handle this requirement, with the aim to find out how the Inspectorate can include this topic in its inspection framework at a later stage (Inspectie van het Onderwijs, 2010d).

Conclusion. NPM is clearly represented in the frameworks and reports of the Inspectorate. The frameworks aim at strengthening educational governance of schools, by emphasizing the quality of self-evaluations, accountability data, and quality assurance systems. The inspectorate furthermore uses output indicators such as graduation rates in risk analyses and inspects educational processes only when schools do not succeed in achieving an adequate output and are judged as being "weak." 
Most thematic reports of the Inspectorate mainly reflect output concerns (examination, early school leaving, literacy standards, labor market perspective) and the state of the art in self-governance of schools, a prerequisite for a distant Department. However, some reports are more concerned with educational processes or the educational context of schools $(850 \mathrm{hr}$ of educational time, competence-based education, complaint procedures, the quality of workplace learning). These subjects sometimes result from educational laws that schools are supposed to respect, laws that are necessary to guarantee a basic quality of all schools. However, these can also be considered infringements on school autonomy, especially when schools perform well on output indicators.

\section{Reports of the Dutch Education Council}

The Dutch Education Council advises the Department, solicited and unsolicited. Here, we focus on the solicited advices in vocational education and on reports about the changing relationship between the Department and schools. In the period 2000 to 2010 , five reports meet these criteria. We will discuss each report shortly.

Direction VET. In this report, the Council reflects upon a policy document with the same name, which outlines the long-term policy for vocational education. The Department chooses a facilitative role in a field where stakeholders are supposed to control the quality of schools; they are considered countervailing powers in a system of checks and balances. According to the Council, the Department should make it more clear which responsibilities still belong to the Department itself, and which responsibilities now belong to schools. The Council suggests that specific responsibilities of the Department concern the quality, accessibility, and cost-efficiency of education. The Department should take a leading, directive role in achieving these goals, and it should also define the minimum requirements of the qualification structure, the curriculum, and the examination in vocational education. The Council also remarks that the introduction of competence-based education needs more consideration and elaboration. It is, for example, not clear what exactly is meant by competencies (Onderwijsraad, 2000).

The Adult and Vocational Act in its implementation phase. In this advice, the Education Council concludes that the Adult and Vocational Act in general works reasonably well. There are, however, some issues that need extra attention. For example, the transition to a qualification structure based on competencies requires clear control by the Department. Because so many actors are 
involved in this process, a coordinating and decisive role of the Department is desired to reach the required uniformity and simplicity of structures (Onderwijsraad, 2001).

The vocational learning chain. Dutch vocational education is preceded by preparatory secondary vocational education, and followed by higher professional education. The Council states that these three sectors are worlds apart to many students and therefore the Department, schools, and the labor market must realize they are all part of the learning chain. The learning careers of pupils must be central, not the courses. The Council advises the Department to introduce a system in which funding applies to the entire vocational learning path of students instead of just parts of it (Onderwijsraad, 2003).

Direction VET: goal oriented autonomy. The Council reflects upon this policy document, the follow-up to Koers BVE (see above). The Department proposes innovations in vocational education but does not want to prescribe in detail how schools should behave. The Council agrees on this idea but thinks the quality of self-governance is not high enough yet to ensure adequate vocational education. The Council then makes several recommendations to improve the self-governance of schools (such as a system to compare schools, protocols for the dialogue between the Department and schools on their output, and clear agreements on what schools want to achieve in collaboration with their environment; Onderwijsraad, 2004a).

Educational governance. The Council formulates two principles for educational governance. The first principle is creating two layers of governance in vocational schools: an executive board and a board of supervisors. In addition, the vocational education and higher education sectors should draft governance codes. The second principle concerns the development of vertical and horizontal accountability. Vertical accountability is accountability to the Department, and horizontal accountability is non-hierarchical and exists mainly of accountability to stakeholders. The Council also recommends that the Department should not prescribe how public accountability responsibilities are to be carried out, but instead it should formulate targets to measure the degree of involvement of societal bodies (Onderwijsraad, 2004b).

Conclusion. The reports of the Education Council about the implementation of NPM clearly uncover the frictions that the Department meets in this process. First, the Council makes clear that it is not enough for the Department to define its facilitative role: It should also be made be very clear what is expected of vocational schools and standards should be measureable. 
Table 3. Values Attached by Vocational Schools and the Department of Education, Culture, and Science to Nine Output and Process Topics (Range $=-5$ to 5$)$.

\begin{tabular}{|c|c|c|c|c|c|c|}
\hline & Department & Schools & Difference & SE difference & $\begin{array}{c}\text { Difference } \\
>.30\end{array}$ & $\begin{array}{l}\text { Significant } \\
\text { difference }\end{array}$ \\
\hline \multicolumn{7}{|l|}{ Educational output } \\
\hline Early school leaving & 3.93 & 3.09 & 0.83 & 0.33 & Yes & Yes \\
\hline $\begin{array}{l}\text { Employer } \\
\text { satisfaction }\end{array}$ & 4.07 & 4.19 & -0.1 & 0.17 & & \\
\hline Numeracy & 2.89 & 2.60 & 0.29 & 0.34 & Yes & Yes \\
\hline Literacy & 3.3 & 3.45 & -0.16 & 0.23 & & \\
\hline Examination & 4.17 & 4.27 & -0.1 & 0.18 & & \\
\hline \multicolumn{7}{|l|}{ Educational processes } \\
\hline Frontal instruction & 1.94 & 3.68 & -1.74 & 0.30 & Yes & Yes \\
\hline Challenge & 4.11 & 3.64 & 0.47 & 0.20 & Yes & Yes \\
\hline $\begin{array}{l}\text { Mentoring in } \\
\text { workplace learning }\end{array}$ & 4 & 4.11 & -0.11 & 0.17 & & \\
\hline Schooling hours & 2.52 & 2.85 & -0.33 & 0.29 & Yes & \\
\hline
\end{tabular}

Second, the council states that the quality of self-governance of schools is crucial. Finally, the Council urges the Department not to forget the interests of students. While the customer, or the student, should be central according to NPM, in reality student interests are sometimes overlooked, for example, due to financial concerns of schools.

\section{Focus of Departmental Policy on Topics Where Schools Disagree}

To answer our second question, we first have to determine on which topics the Department and schools hold different opinions. The next step is to determine whether topics where disagreement exists (especially when these are output topics) obtain more policy attention than topics where Department and schools think alike. For this, we use our analysis of annual reports of the Department described in an earlier section.

Table 3 shows the values vocational schools (teachers and managers) and the Department (inspectors and policy makers) attach to nine topics that refer to educational processes and educational output. The output topics are early school leaving, employer satisfaction, numeracy, literacy, and examination. The process topics consist of frontal instruction, challenge, mentoring in workplace learning, and schooling hours. Frontal instruction and challenge refer to the introduction of competence-based education: Schools were forced 
to reduce frontal instruction, while paying more attention to supposedly more challenging forms of learning.

On four out of nine topics, values of the Department and the schools do not significantly differ. Concerning the output of education, the Department values two topics higher than schools do: early school leaving and numeracy. Concerning the process topics, the schools value frontal instruction higher than the Department, while the Department values challenge higher than schools do.

To classify the level of agreement between the Department and the schools, the topics were then divided in three groups:

- Topics with agreed importance,

- Topics that are significantly more important to schools, and

- Topics that are significantly more important to the Department.

The amount of policy attention was defined as follows:

- Early school leaving receives most attention in annual departmental reports (measured in numbers of pages as well as expenditures). The quality of examination also ranks rather high in the annual departmental reports and tops the list of thematic inspection reports. These two topics therefore are defined as receiving high policy attention;

- Employer satisfaction neither appears in the annual departmental reports nor in the inspection frameworks or reports. This topic is considered as receiving low policy attention; and

- All other topics come up in the annual departmental reports and/or the inspection frameworks and reports. These topics are defined as receiving middle policy attention.

Figure 1 depicts the relationship between agreement on a topic and the level of policy attention that the topic receives. The $x$-axis shows the degree of agreement on topics between schools and the Department. The $y$-axis shows the amount of policy attention the topics receive. Output topics are depicted in black and process topics in white.

We hypothesized that output topics that are more important to the Department than to schools will receive the highest level of policy attention. This hypothesis can only be partly confirmed. Early school leaving is a clear example of a topic that is more important to the Department and receives high policy attention. Numeracy, on the contrary, is also more important to the Department but does not get that much policy attention. In addition, there are three output topics on the importance of which Department and schools agree, but one of them, examination, still leads to a lot of policy attention. 


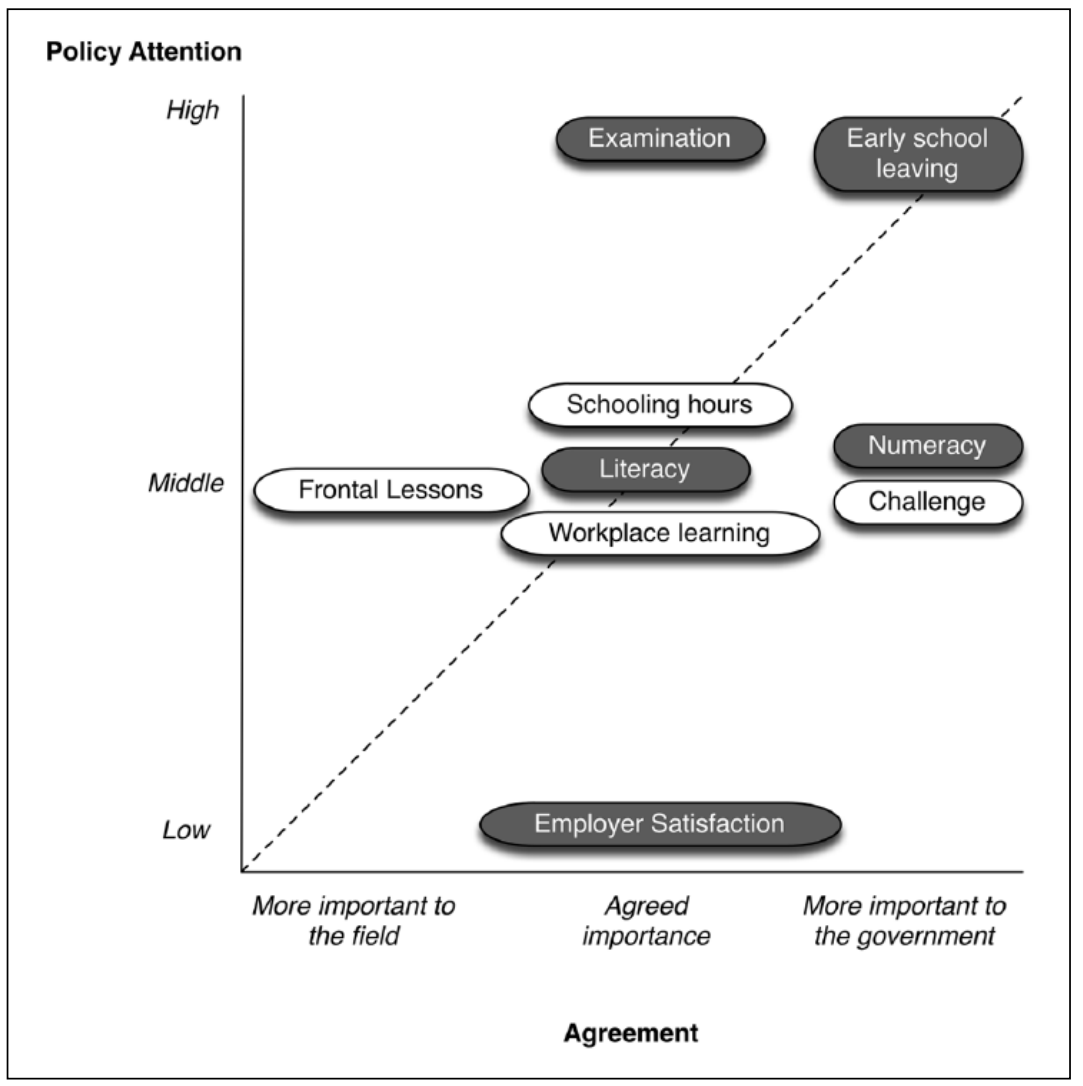

Figure I. The relationship between agreement on topics and policy attention for topics.

Policy attention for process topics is generally lower than for output topics, which is in line with the concept of NPM, but it is not absent. Here, we see again, that the Department keeps developing policy on educational processes even though this is not in line with NPM ideas (see also Conclusions at page 14 of this article). Moreover, the Department does not focus exclusively on process topics where disagreements with schools exist.

\section{Conclusions and Implications}

The influence of NPM is evident in vocational education policy in the Netherlands. We expected that an output orientation and a less prescriptive 
role of the Department would be major characteristics of NPM in education. Indeed, we find a strong tendency toward output measures: Early school leaving takes up a large part of expenditures and policy attention in the annual departmental reports, and examinations receive a lot of policy attention as well. Furthermore, the Department is developing new output indicators such as literacy and numeracy standards. Several policy documents also reflect attempts of the Department to create more distance and leave more autonomy to the schools. Self-governance of schools is stimulated and the inspectorate mainly intervenes in schools that show risks on output indicators and schools whose quality assurance systems are insufficient. Schools performing well are rewarded by less extensive inspection.

Nonetheless we see inconsistencies in the policies of the Dutch government considering the direction they intend to take in terms of NPM. First, the Department is ambiguous by introducing policy programs that are questionable considering the concept of NPM, because they are explicitly focusing on educational processes. The introduction of competence-based education is in that sense a surprise. Although, on one hand, the Department is trying to bring schools at a professional level of self-governance, and to be selfresponsible for their educational processes, on the other hand, it simultaneously interferes by developing rules that affect the content of these processes. Such a step could be rational when the output of schools is not sufficient. The Department then might feel obliged to interfere in failing schools and announce policy measures for them concerning processes that lead to the insufficient output. However, this does not apply to Dutch vocational education when competence-based education was imposed on all schools, regardless of their output. Second, the Department (by means of the Dutch Inspectorate) focuses on legal requirements such as the minimum of schooling hours and complaint procedures. Again, it might be necessary for the Department to develop policy on these topics when the output of schools is at stake. It may be necessary for some schools to pay attention to schooling hours or complaint procedures, especially when their output is not sufficient. But, here too, the Department applied their policies to all schools, regardless of their output. As a consequence, many schools felt their freedom to decide autonomously was hindered. The Department should be clearer about their reasoning behind these policies, and preferably there should be reasons that are linked to the output of schools. Third, the Department develops policy programs on topics even when these topics are already highly valued by schools itself and it may be assumed that schools will do their best to achieve well in these fields. The government should consider whether these policies are superfluous and confusing, because they are not inherent to the path the Department has chosen to follow. 
Instead, we propose that the Department should focus on improving the continuous development of their two main NPM features: sufficient output and school autonomy. Both the output itself and the output indicators are not as good as they should be, and in addition, school autonomy leaves a lot to be desired. Even though there are not as many early school leavers in vocational education as before, the desired numbers have not been achieved yet. The Department should therefore strengthen its policies to reduce the numbers even further in the years to come. In addition, the Department should distinguish between topics they need to invest in (because it can be assumed that schools will not deliberately pay attention to them) and topics they can leave alone (because they are important for and pursued by schools already or because they do not affect output of schools).

The output indicators used by the Department to gain insight into the state of vocational education are very limited thus far. The main indicator is the number of early school leavers. More output indicators can be expected in the near future, such as the levels of numeracy and literacy acquired by students. Furthermore, the government is working on indicators that resemble the value added principle, by looking at the end level of students while taking into account their starting level. A very important output indicator, however, highly valued by both the Department and the schools, is missing in the set of indicators on which schools are judged: employer satisfaction, which may be a central indicator for vocational education.

For educational policy rooted in the concept of NPM, self-governance of schools is central. When schools are not professional in this respect, one of the main pillars of NPM, accountability, is in danger. The Dutch Education Council stressed the importance of further development of accountability already in 2004. In 2010, the Inspectorate stated that a majority of Dutch vocational schools do not live up to the expectations of adequate self-governance. The Department might consider developing a system of bonuses and sanctions for schools that are or are not professional in their self-governance, especially when inadequately governed schools also achieve insufficient output. As of yet there is no such system. However, the Department should be aware of the possible side effects of such a system. Ehren, Leeuw, and Scheerens (2005) point to a potential problem when evaluating the level of self-governance of schools. Schools are expected to develop their own quality assurance system and to use their own quality norms, whereas, in fact, they are rewarded for a specific quality assurance system that only gives reliable information about the indicators the Department prescribes. This will then not add to an improvement of an overall professional self-governance of schools in the long run. Furthermore, although we focus in this article on the Department, we think NPM also implies responsibilities of schools. NPM 
depends on a good self-governance of schools. If schools show themselves to be trustworthy governors of their educational processes, it will be easier for the Department to reduce their interference with them.

\section{Implications for research and policy}

A limitation of the method we used concerns the data we used from the study on stakeholder values in Dutch VET. This questionnaire case study is not representative for vocational education as a whole. As a consequence, we cannot make strong generalizations about Department officials and school representatives. Nonetheless, we think the data give some indication of how interests of the Department and vocational schools differ at certain topics and correspond at others. Future research should seek to further investigate the interests of both parties and how this can enhance the features of NPM. We could only use questionnaire data, but interviews with Department policy makers and members of school management might provide more insightful information in the way NPM policy is developed in the Department and experienced in schools.

Overall, our findings suggest that even though NPM is clearly visible in Dutch educational policy, there are still many elements that do not align with the direction the government intends to take and may sometimes be counterproductive. This can be caused by conditions that underlie NPM and that are not easily met. First, output regulation depends on valid and reliable output indicators, and second, school autonomy depends on a sufficient level of self-governance. To be effective, policy makers have to focus on those conditions. They have to be clear about this and should not wander off to other policy programs. By not being consistent, policy makers send out ambiguous signals. We put forward that a better distinction of policy programs that strengthen or hinder the NPM features, and a better insight in the interest of the Department on one hand and of schools on the other hand, can help to more effectively and successfully stimulate the quality of education.

The literature shows us that the implementation of NPM is often surrounded by an uncertainty by all of those involved and that is not helpful for the quality of education itself. The contribution of this article is the focus on the responsibility of governments to be clear and consistent in how they will incorporate NPM in their policies. We show that it can be useful to look at policy programs in a detailed way. An important question is, then, to what extent the program fits into the broader idea the government wants to pursue. This way, it is easier to pinpoint which aspects of a policy are or are not effective instead of questioning the reform in general. Another lesson from 
literature is that it is, in practice, difficult for governments to grant autonomy to schools. With this study, we want to show that for an effective implementation of NPM, it is valuable to investigate opinions about NPM policies. Governments can grant autonomy more securely if they have an idea of the values and priorities of schools. School officials are more likely to put effort into something that they acknowledge and agree on.

\section{Declaration of Conflicting Interests}

The author(s) declared no potential conflicts of interest with respect to the research, authorship, and/or publication of this article.

\section{Funding}

The author(s) received no financial support for the research, authorship, and/or publication of this article.

\section{Notes}

1. In a prestudy, we studied more departmental documents, but the annual departmental financial reports were the most insightful and specific. Descriptions of questions asked in Parliament and discussions about educational topics were too detailed and scattered to get a good overview of policy programs. A more extensive search in all departmental documents showed that it was hard to distinguish which policy programs were actually executed and for how long.

2. Level 4 is the largest educational level in Dutch VET. A Level 4 course can be described as a training course for a skilled worker at the middle-management level. The duration of a course at Level 4 is 3 to 4 years.

\section{References}

Andersen, S. C. (2008). The impact of public management reforms on student performance in Danish schools. Public Administration, 86, 541-558.

Baker, E. L., Barton, P. E., Darling-Hammond, L., Haertel, E., Ladd, H. F., Linn, R. L., ... Shepard, L. A. (2010). Problems with the use of student test scores to evaluate teachers (EPI Briefing paper 278). Washington: DC: Economic Policy Institute.

Braun, D., \& Merrien, F. X. (1999). Towards a new model of governance for universities? A comparative view. London, England: Jessica Kingsley Publishers.

Byun, K. (2008). New public management in Korean higher education: Is it reality or another fad? Asia Pacific Education Review, 9, 190-205.

Cedefop. (2010). Learning outcomes approaches in VET curricula: A comparative analysis of nine European countries. Luxembourg, UK: Office for Official Publications of the European Communities.

Christensen, T., \& Laegreid, P. (2007). Transcending New Public Management: The transformation of public sector reforms. Abingdon, UK: Ashgate. 
Clarke, L., \& Winch, C. (2007). Vocational education: International approaches, developments and systems. London, England: Routledge.

Ehren, M. C. M., Leeuw, F. L., \& Scheerens, J. (2005). On the impact of the Dutch Educational Supervision Act. Analyzing assumptions concerning the inspection of primary education. American Journal of Evaluation, 26, 60-76.

Fusarelli, L. D., \& Johnson, B. (2004). Educational governance and the new public management. Public Administration and Management, 9, 118-127.

Hangartner, J., \& Svaton, C. J. (2013). From autonomy to quality management: NPM impacts on school governance in Switzerland. Journal of Educational Administration and History, 45, 354-369.

Honig, M. I., \& Rainey, L. R. (2012). Autonomy and school improvement: What do we know and where do we go from here? Educational Policy, 26, 465-495.

Inspectie van het Onderwijs. (2003). Toezichtkader beroepsonderwijs en volwasseneneducatie: Inhoud en werkwijze van het Inspectietoezicht conform de WOT [Supervisory framework in VET]. Utrecht, The Netherlands: Author.

Inspectie van het Onderwijs. (2006a). 850 uur in bve [Schooling hours in VET]. Utrecht, The Netherlands: Author.

Inspectie van het Onderwijs. (2006b). Beroepspraktijkvorming in het mbo [Professional training in VET]. Utrecht, The Netherlands: Author.

Inspectie van het Onderwijs. (2007a). Toezichtkader bve 2007 [Supervisory framework VET 2007]. Utrecht, The Netherlands: Author.

Inspectie van het Onderwijs. (2007b). Meer onderwijstijd in het mbo [More schooling hours in VET]. Utrecht, The Netherlands: Author.

Inspectie van het Onderwijs. (2007c). Onderwijstijd in het vo en bve [Schooling hours in secondary education and in VET]. Utrecht, The Netherlands: Author.

Inspectie van het Onderwijs. (2009a). Onderwijstijd bve 2009 [Schooling hours in VET 2009]. Utrecht, The Netherlands: Author.

Inspectie van het Onderwijs. (2009b). Klachtenbehandeling in het mbo [Complaint procedures in VET]. Utrecht, The Netherlands: Author.

Inspectie van het Onderwijs. (2010a). Toezichtkader beroepsonderwijs en volwasseneneducatie: Werkwijze van het Inspectietoezicht [Dutch Inspection Framework VET]. Utrecht, The Netherlands: Author.

Inspectie van het Onderwijs. (2010b). Klachtenbehandeling in het mbo-2009 [Complaint procedures in VET-2009]. Utrecht, The Netherlands: Author.

Inspectie van het Onderwijs. (2010c). Besturing en onderwijskwaliteit in het mbo [Governance and quality of education in VET]. Utrecht, The Netherlands: Author. Inspectie van het Onderwijs. (2010d). Zorgplicht arbeidsmarktperspectief mbo [The obligation to inform students about labour market perspectives]. Utrecht, The Netherlands: Author.

Karsten, S., \& Meijer, J. (1999). School-based management in the Netherlands: The educational consequences of lump-sum funding. Educational Policy, 13, 421-439.

Leisyte, L., \& Kizniene, D. (2006). New public management in Lithuania's higher education. Higher Education Policy, 19, 377-396. 
Leney, T., \& Green, A. (2005). Achieving the Lisbon goal: The contribution of vocational education and training. European Journal of Education, 40, 261-278.

Lindgren, L. (2001). The non-profit sector meets the performance-management movement: A programme-theory approach. Evaluation, 7, 285-303.

Onderwijsraad. (2000). Koers bve [Direction VET]. The Hague, The Netherlands: Author.

Onderwijsraad. (2001). WEB: Werk in uitvoering [Law on VET: A work in progress]. The Hague, The Netherlands: Author.

Onderwijsraad. (2003). Onderweg in het beroepsonderwijs [En route in VET]. The Hague, The Netherlands: Author.

Onderwijsraad. (2004a). Koers bve: Doelgericht Zelfbestuur [Direction VET: Goaloriented autonomy]. The Hague, The Netherlands: Author.

Onderwijsraad. (2004b). Degelijk onderwijsbestuur [Solid governance]. The Hague, The Netherlands: Author.

Onderwijsraad. (2006). Versteviging van kennis in het onderwijs [Consolidation of educational knowledge]. The Hague, The Netherlands: Author.

Pollitt, C. (2000). Is the emperor in his underwear? Public Management: An International Journal of Research and Theory, 2, 181-200.

Taylor, A. (2009). Mapping the field of VET partnerships. Vocations and Learning, 2, 127-151.

Tolofari, S. (2005). New Public Management and education. Policy Futures in Education, 3, 75-89.

van der Sluis, M. E., Reezigt, G. J., \& Borghans, L. (2014). Quantifying stakeholder values of VET provision in the Netherlands. Vocations and Learning, 7(1), 1-19.

\section{Author Biographies}

Margriet E. van der Sluis (Ph.D) is a Reseacher Specialized in vocational education and school governance. Her recent projects focus on the possibilities of comprehending and using the beliefs of educational stakeholders to improve the quality of vocational education. From 2008-2015 Margriet was employed at the research department of the Dutch Inspectorate of Education. Currently, she works as an Educational Consultant at BMC Groep.

Gerry J. Reezigt (Ph.D) is a Senior Researcher and Inspector at the Dutch Inspectorate of Education. Her research concentrates on effective school and classroom characteristics and school board governance.

Lex Borghans is a Professor of labour economics and social policy at the Department of Economics and the Research Centre for Education and the Labour Market (ROA) at Maastricht University. His current research focuses on the optimal structure of education from an economic perspective and the significance of non-cognitive skills. 